\section{DEVELOPMENT OF A LAND USE POLICY FOR SASKATCHEWAN}

In 1976, delegates from twenty major provincial organizations met to discuss the need for a land use policy and land use policy guidelines. Delegates to the first Workshop recommended that a follow-up conference be held following detailed review and analysis of the results of Workshop I by paricipating organizations. A second land use Workshop was held in April, 1977.

Delegates to Workshop II were askd to submit briefs outlining the reacions of their members. The brief resented on behalf of the askatchewan Natural History Society yy Dr. G. Ledingham appeared in the March, 1977 issue of the Blue Jay. riefs were circulated to all rganizations prior to the Workshop. An analysis of these briefs was oresented to Workshop II delegates or discussion. Delegates reached a concensus on some guidelines for use of various types of land including gricultural land, mineral land, water leritage land, settlement lands, fish and wildlife, waste disposal land, orestry land, utility land and recreaion land. Workshop delegates greed that there should be further oublic involvment in the developnent of a land use policy.

In October, Hon. Neil Byers anlounced the formation of a Land Use olicy Committee with represenatives from six provincial rganizations (Saskatchewan Urban Municipalities Association, askatchewan Wildlife Federation, nvironmental Advisory Council, ask. Federation of Agriculture, Sask. Mining Association and the Sask. Association of Rural Municipalities). he Land Use Policy will undertake a and use education and information rogram and seek public reaction to roposed land use quidelines. The Committee will also review and adise on policy development activities nitiated by government.

The Interagency Co-ordinating Committee comprised of the perma- nent heads of 12 major departments and Crown corporations will be responsible for land use policy development activities of all government departments and agencies concerned with land use in Saskatchewan. Chairman of both committees is Grant Mitchell, Deputy Minister of the Dept. of the Environment.

Government has approved use of the guidelines, which were agreed to by delegates at Workshop II, in land use decision making until a comprehensive land use policy has been formulated and adopted by the government.

SNHS members are urged to participate in public meetings on land use which will be held throughout the province beginning early in the new year.

A copy of Land Use Workshop II Summary Report which outlines the approved guidelines for various land uses can be obtained from the Department of the Environment, 1855 Victoria Avenue, Regina, Sask. S4P 3T1

\section{LAND USE IN SASKATCHEWAN}

\section{P. C. RUMP \& KENT HARPER}

Policy, Planning \& Research Branch, Saskatchewan Department of the Environment

January, 1977.

The colour print on the cover of this 192 page publication by Environment Saskatchewan shows a marshy area in the foreground, scattered clumps of trees in the distance, and cropland and a farmstead in between. The potential for land use conflicts is there, but the recognition of those conflicts is dependent on the interpretation of the viewer.

The short preface explains that the "report," originally prepared for delegates to the 1976 Saskatchewan Land Use Forum, was designed to provide quick access to pertinent facts about Saskatchewan's land. If 